\title{
The play's the thing: Theatre professionals make sense of Shakespeare
}

\author{
Michael R. Olsson \\ Lecturer, Journalism, Information \& Media Studies, University of Technology, Sydney \\ Address: PO Box 1234, Broadway NSW Australia 2007 \\ Email: Michael.Olsson@uts.edu.au
}

\begin{abstract}
This paper reports on the findings of a study examining how theatre professionals (actors, directors and others) make sense of the works of a culturally iconic author (William Shakespeare). The study aims to address critique of the information studies/science field's excessive focus on active information seeking and searching by developing an alternative approach. The study seeks to understand sense-making as more than the problem-solving behaviour of individuals: to see it as an embodied, social process, involving emotion as well as rationality. In doing so it draws on theoretical approaches from a range of different disciplines and traditions, including Dervin's Sense-Making, Foucault's discourse analysis and Derrida's deconstructionism.
\end{abstract}

\section{Introduction}

Admit me Chorus to this history;

Who prologue-like your humble patience pray

(Henry V)

Since at least the mid-1980s, with the rise to prominence of the "user-centred paradigm" (Dervin \& Nilan, 1986), information researchers, particularly those associated with the emergent discipline of information behaviour research (Savolainen, 2007), have been claiming to have moved beyond a 'systems-centric' worldview - to have moved beyond a focus on libraries, databases and search engines to a more holistic approach based on understanding the needs of the information seeker. Information behaviour researchers, in particular, have claimed that theirs is a discipline which studies "the totality of human behaviour in relation to sources and channels of information, including both active and passive information seeking and Information use" (T.D. Wilson, 2000, 49).

Since the 1970s, with the work of Patrick Wilson (1977), a range of theoretical and empirical work (e.g. Erdelez, 1996; Williamson, 1998) has highlighted the importance of informal information behaviour, such as interactions with colleagues. Bates (2002) estimated that $80 \%$ of information is incidentally acquired or absorbed rather than purposefully sought, while T.D. Wilson (2000) has emphasised that active information seeking and searching makes up only a small percentage of people's information behaviour. 
Despite this, as a range of critics (e.g. Julien, 1999; Talja, 1997;; T.D. Wilson, 2000) have pointed out, the overwhelming majority of research in the field continues to focus on active information seeking and searching, with the most commonly studied groups continuing to be certain 'elite' professional and academic groups, such as university students and researchers. As Julien points out:

A sober analysis of our user-centredness reveals that what we continue to be particularly interested in is the user of information systems, with scant attention to the non-user of formal information systems. Thus user-centredness is essentially an approach not unlike systems-centredness (Julien, 1999, p.207).

This tacit focus on systems rather than people has led to an essentially atomistic approach to constructing information behaviour. Major models of information seeking/behaviour (e.g. Ellis, 1993; Krikelas, 1983; T.D. Wilson, 1997) follow a common pattern: a recognised information need/gap/anomalous state of knowledge is seen as instigating active information seeking; this active seeking continues until the need is met/gap is filled or the seeker abandons the search. The parallels between such 'fairy-tale' models (like fairy tales, they have a clearly defined beginning, middle and an end) and a systems-centric world view are clear: they echo the pattern of many information professionals' interactions with their clients, such as a reference interview or a database search i.e. beginning with defining a query, proceeding through purposive searching and concluding with the client supplied with 'information'. Yet the question we need to ask ourselves is: while such models might effectively represent the information professionals' view, are they equally effective at representing other people's sense-making processes? Are they compatible with the field's stated desire to develop a holistic understanding of people's relationship with information?

In response to critique of prevailing approaches, Savolainen (2007) has identified the emergence of a counter discourse, which he calls 'Information Practice', in opposition to the prevailing 'Information Behaviour' discourse. Savolainen follows Talja in suggesting that the key characteristic of this new discourse is that it represents "a more sociologically and contextually oriented line of research" ( $p$. 120) which:

...shifts the focus away from the behavior, action, motives and skills of monological individuals. Instead the main attention is directed to them as members of various groups and communities that constitute the context of their mundane activities (Savolainen, 2007, p. 120).

The research in this paper is connected to this emerging discourse, drawing on its understanding of the essentially social nature of the relationship between people and information, while at the same time exploring aspects of the social construction of knowledge that have been largely unexamined by information researchers. Both meta-theoretically and methodologically, it is a hybrid, drawing not only on existing information behaviour/practices research but on a range of different ideas and approaches from a variety of disciplines in order to develop an alternative approach. It been strongly influenced by theories and techniques derived from the work of post-structuralist theorists such as Michel Foucault (1972, 1977, 1980; Rabinow 1984), and Jacques Derrida (1992, 1997), as well as Erving Goffman's $(1959,1983)$ work on the embodiment of knowledge, and the more recent developments of Dervin's Sense-Making (1999). The aim was to develop a more holistic approach: one that looks beyond the active seeking of individuals to consider sense-making as a complex and 
ongoing process, one involving bodies and emotions, as well as language and intellect, both the product and the creator of a social (discursive) environment.

\section{Problem Statement}

Once more unto the breach, dear friends

(Henry V)

The aim of the present study was therefore to examine the question 'How do theatre professionals (actors, directors, designers etc) make sense of the works of a culturally iconic author (William Shakespeare)?' - how do they, individually and collectively, go about transforming texts written more than four centuries ago into a living breathing, theatrical experience relevant to a heterogeneous modern audience?

Shakespeare in performance was chosen as the focus of the research for two key reasons. Firstly, despite Shakespeare's acknowledged role as an important figure in the cultural heritage of the English-speaking world, it is a context that has been almost entirely ignored by information researchers. Secondly, by working with a community who the scant existing literature suggested were largely non-users of formal information systems, a community that were known to recognise and value 'emotional truth', It was hoped to find a fruitful context in which to examine sense-making - how people became informed - in a different way: one which transcended prevailing approaches focus on active searching and logical problem solving.

\section{Literature Review}

As, painfully to pore upon a book

To seek the light of truth

(Love's Labours Lost)

The study was interdisciplinary in its approach drawing on a range of literatures, including information behaviour research, communication theory, discourse analysis, philosophy and performance studies. These divergent literatures helped shape the study's meta-theoretical and methodological approach, as well as providing insights into the complexity of the context to be studied.

\subsection{Why Theatre? Why Shakespeare?}

He was not of an age, but for all time! (Jonson, First Folio)

Despite the acknowledged importance of theatre - and Shakespeare in particular - in the Western world, and despite being the object of research in a wide variety of other disciplines, there has been very little empirical research examining the information behaviour of theatre professionals, indeed of artistic communities in general. Much of what research there has been (e.g. Atkins, 2001; Cobbledick, 1996; Pilch, 1987 ) has focused almost exclusively on their need for and/or use of formal information sources and services, such as libraries and databases. A notable exception to this is 
Davies (2007), which examined the role of a text (prompt book) as a temporal boundary object "abstract or concrete objects which both inhabit several intersecting social worlds and satisfy the informational requirements of each of them" (Davies \& McKenzie, 2004). This study suggested that texts play a vital role in the negotiation and coordination of the disparate understandings and expertises of members of a theatre company. Examining this question would also play an important role in the present study.

Shakespeare is widely acknowledged to be the single most influential author in the history of the English language. His work has been the object of centuries of literary and academic attention in fields as diverse as literary criticism, performance studies, history, philosophy, cultural anthropology, sociology, cultural studies and psychology and his writings continue to have a profound effect on the everyday language use of billions around the globe (McCrum, 1986). The history of theatrical productions of his work is extraordinarily rich and diverse, with major professional productions of Shakespeare in Australia in recent years, for example, drawing inspiration from sources and issues as diverse as Freudian psychology, Japanese kabuki and the indigenous land-rights debate (Golder \& Madelaine, 2001). Productions of Shakespeare are a lens through which audiences can see reflected society's constantly changing attitudes to love, war, family, jealousy, the supernatural, gender etc. how they define what it means to be human.

Despite the prevalence of the view of Shakespeare, first fostered by Ben Jonson in his dedication of the First Folio of 1623, as a 'timeless' genius whose works contains a 'universal' truth, it is clear that every production of Shakespeare is - indeed, must be - different: the product of the sense-making processes of different people, with different beliefs and understandings operating in different organisational/cultural/artistic/national contexts performing in different places for different audiences. As a consequence, examining how theatre professionals make sense of Shakespeare in order to turn centuries-old words into a living production for a contemporary audience, was the perfect site to study Barthes and Foucault's concept of 'death of the author' (Barthes, 1988; Foucault, 1972, 1977, 1980; Rabinow, 1984) - the idea that meaning is not determined by authors but constructed by readers (and in this case, audiences). The study has sought to explore the interplay of how these diverse constructions - as well as the sometimes convergent, sometimes divergent interests of actors, directors, designers and technicians - interact in the cooperative environment of producing a theatrical production.

\subsection{Sense-Making, Discourse and Embodiment}

What a piece of work is a man, how noble in reason, how infinite in faculties, in form and moving how express and admirable, in action how like an angel, in apprehension how like a god!

(Hamlet)

A key aim of the present study was therefore to develop a theoretical and methodological approach to information research which addressed critique of prevailing approaches as atomistic and implicitly systems-focussed. Also, while the influence of cognitivist approaches since the early eighties led to a discourse that constructs information behaviour primarily in terms of the mental processes of individual information seekers, or as Belkin describes them "information processing devices" (1990, 
p. 12), the present study aimed to develop a more holistic understanding of the relationship between people and information.

While Dervin's Sense-Making remains highly influential amongst information researchers, most citations continue to be to earlier, more individually-oriented, work from the 1980s or early 1990s (Clark \& Archer, 1999). This may be why Sense-Making tends to be constructed in our field as a theory relating to the information seeking of individuals and thus closely allied to other models of information seeking behaviour by Belkin, Kuhlthau, Ellis etc. (T.D. Wilson, 2000). Yet Dervin's more recent writings have increasingly distanced Sense-Making from such a construction, positing that sense-making is a more complex and less linear process:

...embodied in materiality and soaring across time-space ...a body-mind-heart-spirit living in time-space, moving from a past, in a present, to a future, anchored in material conditions; yet at the same time with an assumed capacity to sense-make abstractions, dreams, memories, plans, ambitions, fantasies, stories pretences that can both transcend time space and last beyond specific moments of time space (Dervin, 1999, p. 730).

It was this view of sense-making as a complex, embodied process that the present study would seek to explore.

Dervin's Sense-Making approach is grounded in the assumption that all sense-making is situated inextricably linked to the social context in which the sense-making occurs. In this, as Talja (1997) has pointed out, there are clear parallels between Dervin's work and that of post-structuralist theorists such as Michel Foucault (1972, 1977,1980; Rabinow 1984), and Jacques Derrida (1992, 1997). Foucault's theories on the discursive construction of power/knowledge have been used by a number of writers in an LIS context (e.g. Frohmann 1992; Olsson 1999, 2005, 2009; Talja 1997;) to problematise and challenge some of the key assumptions that underpin existing approaches to information research and Foucault's approach to discourse analysis has been another major influence on my work, including this study.

Foucault argued that knowledge is not objective - to be measured in terms of its supposed correspondence to an external reality - but rather an intersubjective social construct, the product of the shared beliefs and interpretive practices (what Foucault called the discursive rules) shared by a particular community or communities at a particular point in space and time. "For Foucault, there is no external position of certainty, no universal understanding that is beyond history and society" (Rabinow, 1984, p. 4). Derrida's deconstructionist approach is grounded in a parallel worldview. Derrida argues that since all meaning is contextual and based on difference, any philosophical or social theory that claims to uncover a 'fundamental' truth is inherently flawed. His deconstructionist approach is thus a "method for revealing the radical contextuality of all systems of thought" (Dickens and Fontana 1994, p. 8).

Another key feature of Dervin's more recent writings on sense-making is that "Emoting ...usually marginalized as a non-useful strategy for sense-making takes equal footing along with factizing" (Dervin, 1999, p. 732). This is in marked contrast to prevailing approaches to information seeking research where affective factors tend to be regarded as "at best only an annoying interference with effective application of cognitive skills to information retrieval but ..., at worst, are the primary barriers to information retrieval" (Julien, 1999, p. 586). While recent times have seen a growing 
interest in the role of emotion in information behaviour (e.g. Nahl \& Bilal 2007), much of this research is individually focussed and essentialist in its construction of emotion - viewing affect as fundamentally acultural. If discourse analysis has shown us that language is not a neutral conveyor of ideas but rather the product and generator of discursive power/knowledge, then the present study aimed to explore the social role of emotion - its social construction, the meaning/s and authority it might convey. The study's theatrical context offered a unique opportunity here: in contrast to most Western professional and academic discourses, the theatre is a context where 'emotional truth' is recognised as an important and legitimate part of the creative process.

While cognitivist theories have led many researchers to construct information behaviour as an essentially mental process, Dervin emphasises that sense-making is an embodied process. This would also be a major focus of the present study, informed also be an emergent study of the embodiment of knowledge in the discourse analytic literature (Coupland \& Gwyn 2003).

Embodiment is not a concept that information researchers have given much attention, with the notable exception of the information literacy work of Annemaree Lloyd (2006, 2007). Her doctoral work, studying firefighters, which has many parallels with the present study, found that "[b]ecoming information literate ... requires experience with social and physical modalities as well as with textual information" (2007, p. 181). The study found that "[i]nformation from the corporeal modality is highly valued ... "you can't develop fire sense just by reading about it"” (2007, p. 188). The present study would also find that participants' sense-making combined social, physical and textual information practices.

\section{Methodology}

Though this be madness, yet there is method in't.

(Hamlet)

As with its theoretical underpinnings, the study's methodological approach drew on elements from a variety of fields and research traditions, including discourse analysis, Sense-Making and information practices/behaviour research. Bringing together elements from these disparate research traditions involved the development of a hybrid methodology.

The findings of the study are based on interviews with 35 theatre professionals in Canada, Finland and the UK, including 14 from the Stratford Shakespeare Festival of Canada, North America's largest and most prestigious classical repertory theatre, and 12 from Shakespeare's Globe in London. Other participants include actors, writers and directors associated with the Royal Shakespeare Company, the National Theatre and the Central School of Speech and Drama in the UK and the Tampereen Työväen Teatteri (Tampere People's Theatre) in Finland. Participants included actors, directors, set and costume designers, voice coaches, dramaturges and writers, with some participants having experience in more than one such role. While some participants were purposefully sampled and directly approached by the researcher, the majority (28) were recruited via snowball sampling (Patton, 2002), with one participant nominating other theatre professionals (in their own company or elsewhere) they felt should be included in the research. The first 25 interviews were carried out in July-December 2007 in Canada, Finland and the UK, while the researcher was a visiting scholar at the 
University of Western Ontario, University of Tampere and Shakespeare's Globe in London; while a further 10 interviews were carried out in July 2008 during a second, four week stay at the Globe.

The study began by adopting a semi-structured approach to interviewing, using a guide (see Appendix I) incorporating aspects of the 'Life-Line' techniques developed by Dervin and her collaborators (Dervin \& Frenette, 2001). As the study progressed however, its approach was increasingly influenced by the less structured, more conversational approach advocated by Seidman (1991) as a means of empowering the participants and reducing the influence of the researcher's preconceptions. Participants were asked to describe the events and relationships that have shaped their relationship with Shakespeare and his work, as well as Shakespeare's 'place' - in their own work, in the academy, the theatre world, and in contemporary society.

One major challenge of the present study was that many of the participants, especially actors and directors, were very used to being interviewed - talking to the press being part of their job. This had both positive and negative aspects. On the one hand, these participants were confident and comfortable in talking about themselves, with a ready supply of amusing anecdotes to hand. However, this meant that it was important to develop strategies that probed below the polished surface of these oft-told stories, to have participants reflect on what events and relationships were important - and why.

Overall, the research was successful in achieving this - even the briefest interview (cut short by the participant's time constraints) lasted just over an hour, with many running more than two or even three hours. A number of participants commented that they found the interviews a revealing process, offering them an opportunity to reflect on their professional life in a way they had not done before. The interviews were digitally audio-recorded and transcribed prior to analysis.

Given the hybridity of the study's theoretical and methodological approach, this was clearly a study that would need to follow Phillips and Hardy's advice: "the researcher will need to 'customize' his or her method of analysis in light of the particular study at hand" $(2002$, p. 78). Although broadly discourse analytic in its approach, seeking to identify the ways in which participants spoke about their experiences and the common discursive repertoires they drew on to do so. In doing so, the study's analysis also adapted iterative, inductive 'constant comparison' techniques (Glaser \& Strauss, 1967; Miles \& Huberman, 1994), while at the same time rejecting the naive empiricism sometimes associated with the grounded theory tradition. As discussed below, the analysis drew on ideas from Dervin, Foucault, Goffman and others to inform the researcher's understanding of participants' accounts. At the same time, these theories were themselves problematised through their application to a context quite different from that for which they were originally conceived. In this way, established theory informed the researcher's understanding of the data, while, at the same time, the data raised important questions about the theory. This process involved both a detailed microanalysis of the interview transcripts, aided by the use of NVIVO software, as well as the broader thematic writing techniques advocated by Glaser and Strauss (1967) to explore emergent trends, concepts and theories. Participants played an active role in the analysis process through follow-up interviews, email correspondence, etc. 


\section{Findings}

There are more things in heaven and earth, Horatio,

Than are dreamt of in your philosophy.

(Hamlet)

The study's findings produced a very rich picture of both the information practices the participants engaged in to make sense of Shakespeare - a portrait in many ways at odds with the assumptions underpinning prevailing approaches to information behaviour research.

\subsection{People and Texts}

When shall we three meet again in thunder, lightning, or in rain?

(Macbeth)

As in previous research (Olsson 2005, 2007), a strong feature of the findings was the relative lack of importance participants attached to purposive information seeking, especially of formal information sources or systems, with only a minority (6 -two dramaturges, one writer, one voice coach and two actors) reporting it as a significant part of their sense-making.

While a significant minority (14 participants) did talk about reading academic literature relating to Shakespeare and/or the Elizabethan/Jacobean period, this was overwhelmingly described as a background activity, something largely engaged in between or in the early planning stages of productions, something there was "no time for once the real work starts" (Jaques, director). The texts were far more likely to be chosen as the result of a personal recommendation from a colleague than via purposeful searching.

Many participants regarded most of the published Shakespearean literature - whether literary criticism or performance studies as not useful:

When I read most of what's written, I just roll my eyes! I find myself thinking "Have they ever seen the play?" They're off in their own world and I don't think it has much to do with what I do... (Hero, Actor)

Well, let's face it, most of them [performance studies academics] think they know better than us - secretly think they could do better than us - but they can't! If they could they'd be doing it... (Mercutio, Director)

Indeed, this suspicion of the academy was a strong feature of many participants' accounts: it was a discourse characterised not only by a belief that academic writing on the subject was obscure and irrelevant but a suspicion that academics look down on theatre professionals. One interesting consequence of this was that many participants were much happier talking to me once they ascertained that I wasn't 'one of them' - that I was not an English literature or performance studies academic. Clearly participants viewed themselves as standing outside the academic power/knowledge hierarchy but at the same time part of a different community with its own techniques for determining meaning and authority. 
Instead of searching for information, the events that participants described as having the greatest influence on their understanding of Shakespeare were 'social' interactions: informal conversations with their colleagues or mentors, interactions at rehearsals - social activities associated with their role/s as actors, directors etc.:

You learn the most just being in the rehearsal room with other actors ... not that you try and copy them but just seeing how they work, what the process is ... when I understudied for Julia, it was like following her tracks in the snow ... you know, I could see where I should put my feet... (Portia, actor)

Really, it's only when you talk to the director, get a sense of what his vision for the production is, that I can really start to think about my designs. Then I can start coming up with ideas ... see what he thinks... (Sebastian, designer)

Participants in the study frequently explicitly linked their engagements with texts to their interactions with other people:

Obviously l'd read the play, done background research, seen it on stage but it wasn't 'til I got into the rehearsal room, starting working with lago [the director] and the other actors that I really started to feel I understood it ... that's usually how it goes. (Timon, actor)

When I start out on a new production, I work a lot with our dramaturge. We discuss the text ... I rely on her expertise. And then very often, she'll go out and do some research, based on what we've talked about and come back to me. (lago, director)

In two companies, the dramaturge was seen, both by him/herself and by other members of the company, as having an 'information professional' role - seeking out useful literature on behalf of actors and directors:

Part of what I do is find out what will help them. One actor might want to know all about the actual kings and queens of England, another might want to know about how such and such a metaphor comes from hawking, so they want to know about that. Others want to know about what people thought about ghosts at the time... (Andromache, dramaturge)

We have a wonderful dramaturge [Andromache] and she's always coming in with a wonderful range of books and articles, which she leaves in the rehearsal room and that you can take away with you... (Cressida, Actor)

The presence of the dramaturge effectively acting as information professional may in part explain participants' relative lack of use of information services and systems, although the was little indication that those not working with such a dramaturge engaged in more active searching.

In contrast to the Need-Seeking-Satisfaction model (Krikelas, 1983), it was clear from participants' accounts that their sense-making was seldom a linear process: 
...it's hard to describe, you're reading, you're talking to the director, working with the other actors, doing sessions with the voice coaches, the movement coaches - and all of this is part of your process as you're working out who your character is. (Portia actor)

Rather than a series of isolated encounters with information sources, participants spoke of the ongoing nature of their relationships.

I've worked with lago before ... I love working with him... You develop a sense of what he wants .... you don't have the worry "Is this what he means?" (Timon, actor)

Each individual encounter (whether with a person or a text) built on the participant's previous experience, enriching their constructions of both Shakespeare and their informants.

\subsection{Affective Discourse}

I will wear him

In my heart's core, ay, in my heart of heart,

(Hamlet)

Theatre professionals in general, and actors in particular, demonstrated a strong awareness of the importance of emotion for their sense-making:

As an actor, you need to do more than understand the play in an academic way... you need that emotional connection to the character and to the story. I need to FEEL it! (Imogen, Actor)

Furthermore, the discussion of affective factors - 'emotional truth' - was an acknowledged, indeed commonplace feature of theatre professionals' interactions with one another, especially amongst actors and directors:

Some directors are more interested in the spectacle ...treat you like a puppet - "Go down stage and stop here". But the really good directors, what I call 'actor's directors', who really help you find the character, talk a lot about what you character should be feeling at that point in the play. (Antony, Actor)

Emotion, for participants, was clearly more than a matter of hormones and endorphins, it was a social construct. Their exploration and interpretation of their emotions was the product of established social practices within the theatrical community and the focus of much discussion.

A striking example of this is shown below. Whereas information research, with its focus on problemsolving, might lead us to assume that the question asked would be "What do I need to know?", instead the participant tells us:

I was having trouble with one scene, so I went and talked to another member of the company, who I knew had played the part before... I asked him "What should I be feeling at this point?" (Timon, Actor) 
Thus, amongst theatre professionals, 'emotional truth' is both the subject and the generator of discourse, a socially-validated practice and an acknowledged source of authority. The social construction of affect plays a key role in the sense-making not only of individuals but of the company as a whole. This may be a contributing factor in many participants' tendency to regard academic writing on Shakespeare, with its conspicuous lack of an affective component, as "dry", "sucking the life out of it".

\subsection{Embodied Sense-Making}

Then imitate the action of the tiger:

Stiffen the sinews, summon up the blood.

(Henry V)

For theatre professionals, understanding Shakespeare involved much more than a cerebral process: their professional lives are based on the ability to embody their knowledge: they need to manifest their understanding in the physical world as physical actions in physical space. Designers need to do this through set and costume designs, directors through 'blocking' the movements of their actors, constructing the action to suit the confines and challenges of a particular physical space:

As I'm going through the text, I need to constantly think about how I'm going to make this work ... especially in this theatre with its long thrust stage and audience on three sides... sometimes an actor is going to have to be acting with his back. (lago, director)

They therefore read the text of Shakespeare's plays through the lens of their material concerns. At the same time, their physical environment can shape their understanding of the text:

We've learned so much working here at the Globe. You realise that Shakespeare was actually writing for this stage. For example, I've found that many of the major speeches, the soliloquies, give actors exactly enough time to get from the balcony above to the main stage. (Horatio, actor and voice coach)

For actors, embodiment is a much more literal process; they need to physically become their character (at least for a few hours' traffic upon the stage):

I need to find the character's voice ... the way they move. That's where the voice and movement coaches can be so helpful. (Portia, actor)

A bunch of the young actors, we formed 'Medieval Fight Club' ... we'd get in one of the big rehearsal rooms and really go at it! Because it's no good coming across as a bunch of actors playing about with prop swords, you need to look like you know what you're doing. ...at the same time, it gave me a real insight into the character... as a warrior. (Timon, actor)

Actors' accounts make it very clear that for them to make sense of a character involves not only intellectual and affective elements but also physical ones: how the character walks, talks, laughs etc. - it is this embodied knowledge that is the basis of their performance. 
As with affect, it was clear that the participants embodiment of their knowledge was not an idiosyncratic, individual process. Actors, for example, would work with the director, voice and movement coaches and other actors to develop an embodied performance designed to convey the 'truth' of the character to the audience. It was a social process; drawing on established conventions and accepted practices - they demonstrate that theatre professionals have discourses of the body, as well as linguistic discourses.

\subsection{Creativity Vs Authenticity}

Speak the speech, I pray you, as I pronounced it to

you, trippingly on the tongue

(Hamlet)

Making sense of Shakespeare was at the heart of the professional, creative lives of all the study's participants. It was a subject that all participants had thought deeply and cared passionately about. For many, it was a question they had literally dedicated their lives to. Yet in analysing the ways in which participants talk about Shakespeare, one is struck by what appears to be a paradox: they all draw on two essentially contradictory discourses.

The first of these, allied to the long-standing tradition of viewing Shakespeare as a 'universal genius', valued authenticity:

I feel it's a great honour and a great responsibility to do this work in an authentic way: to be true to Shakespeare's language ... these characters... Shakespeare is bigger than all of us. (Robin Goodfellow, Actor)

This discourse leads theatre professionals to read Shakespeare in a particular way - to seek out its 'true' meaning, clues to authorial intent. This is a discourse that seeks to deny that meaning is something created by the reader, even as they are engaged in exactly this process. Adverse comments about post-modern academic approaches to studying Shakespeare, evident in six participants' accounts, may be partially attributable to this discourse.

Related to this was another discourse, particularly prevalent in the Globe and Stratford companies, one which saw theatre professionals as the 'true custodians' of Shakespeare's work:

You know, I don't think you can really understand Shakespeare, until you perform it ... the plays were written to be performed, not read. (Poins, actor)

It's kind of amazing to think of yourself as being part of a tradition that goes back through the centuries ... to Shakespeare and the Globe. And I think you feel a responsibility to carry on that tradition, to honour it. (Seyton, actor)

At the same time, all participants' accounts also showed an understanding that interpretations of Shakespeare had changed over time, and that their adaptability was a key feature of their enduring popularity:

The reason that this stuff has lasted for as long as it has is.... that there are as many different ways of interpreting it as there are people coming to it. (Hippolyta, actor) 
This understanding was the basis for the other major discourse present in all participants' accounts: the creativity discourse. This discourse is one that values originality of artistic expression. It can be seen, for example, in many actors refusal to see other productions/films of the play because:

I don't want to just copy what's been done before. I need to make the part mine... find my own truth. (Timon, Actor)

Drawing on this discourse, each participant would strive to bring something "new and fresh" to each new production:

We wanted to make this production very political, quite Marxist...Show Shakespeare in a new way, different to what the audience expects (Puck, actor)

You need to find new settings, new approaches to the design ... get away from 'pumpkin pants' Shakespeare! (Sebastian, designer)

Allied to this discourse, is a concern with making the plays relevant to a contemporary audience:

How do you get across the idea of what royalty means to a modern audience? I mean they weren't nice polite guys cutting ribbons ... They were more like mafia dons! (Rosalind, voice coach)

These two discourses are frequently in opposition in participants' accounts, with the one being used to critique the other:

You know, in many ways I envy my overseas colleagues who get to work with Shakespeare in translation, because they don't have to worry about the problems of archaic language that audiences can't understand ... but we're all "You can't change it, it's SHAKESPEARE!" (Andromache, dramaturge)

Well we have a director now, he's very focussed on the look of the thing, making a big spectacle, but to me that's going against what Shakespeare is about - the characters, the language... (Antony, Actor)

It would be a mistake to see participants' use of two apparently contradictory discourses as a 'problem', some failure on their part to comprehend the 'truth'. Discourse analytic scholars have long understood that complex topics will invariably give rise to multiple discourses and that individuals will move between these discourses as circumstances dictate. Furthermore, it is clear from the study that this apparent paradox is not a weakness but a strength. Were the 'authenticity' discourse to be dominant, the likely outcome would be theatre that was simply an exercise in historical recreation, of interest to only a few scholars. Conversely, a production where the 'creativity' discourse was pre-eminent may be rejected by the audience (as avant-garde productions frequently have been) as 'not Shakespeare'. The competing claims of these two discourses frame the 'battle for truth' (Foucault) within each production, it is the creative tensions between their competing claims that makes each new production both unique and connected to tradition - it is the beating heart of Shakespeare as a living theatrical experience 


\subsection{National Voices}

Cry 'God for Harry, England, and Saint George!'

(Henry V)

Nowhere was the battle between the creativity/contemporary relevance and authenticity discourses - and their implications for participants' embodiment of their knowledge - clearer than in the extensive discussion of accent by both Canadian and UK participants:

There's a lot of argument her as to whether you should say "the duke" ... or "the dook". (Rosalind, voice coach)

In both countries, there were a number of participants, both actors and directors, who wanted to move away from the Received Pronunciation (RPC - BBC/public school English) of 'traditional' Shakespearian productions to use accents more like the everyday speech of the audience:

I don't see why an Ancient Greek character needs to sound like he went to Eton! (Zero, director)

Contemporary accents, some argued, not only made the characters more accessible to the audience but could be used to convey meaning:

One of the best productions I've seen was a Romeo and Juliet from Quebec... the Capulets were Francophone and the Montagues were Anglophone... (Rosalind, voice coach)

Interestingly, the authenticity discourse could also be employed to justify such an approach:

We had a talk from a language professor from England and he said that the accent in Shakespeare's time would have sounded much more like Americans then RP... (Antony, Actor)

Two Scottish participants made a similar argument:

The language works so much better in Scots - it's more raw, visceral ... and there is a much greater range of sounds... (Poins, actor)

Their spontaneous performance of various speeches to demonstrate this were not only convincing but mesmerising - in a way that no words on a page can convey!

These quests for authentic, national voices are another good example of the social nature of participants' sense-making: they both draw on and challenge established discursive repertoires and embodied practices. At the same time they demonstrate participants' ongoing awareness that they need to make sense of Shakespeare's texts, not just for themselves but for their audience.

\section{Conclusions}

All the world's a stage,

And all the men and women merely players: 
They have their exits and their entrances;

And one man in his time plays many parts

(As You Like It)

In seeking to develop a different theoretical and methodological approach, the study has aimed to highlight the importance of aspects of people's information practices that have been largely unconsidered in existing research in the field, such as affect as a discursive construct and the embodiment of knowledge. Its aim in doing so has been to develop an alternative approach which allows us a greater understanding of the complexity of people's individual and collective sensemaking.

It is hoped that some of the concepts and issues the study raises may be applied and adapted by other information/knowledge researchers- that a study of a traditional Western cultural icon may make a contribution to the emergence of a new kind of information research in the $21^{\text {st }}$ century. In a world that increasingly recognises the limitations of western thought's post-Enlightenment privileging of objectivist rationality, information researchers need to adopt a more holistic approach to understanding how people make sense; an approach which acknowledges its affective as well as its rationalist components. Equally, the time may be ripe for information researchers to look beyond a Cartesian model of knowledge-as-cognition: to consider what theatre professionals already know: that knowing can be a matter for bodies, as well as for minds.

P. Wilson (1997) has highlighted that information researchers' focus on information seeking has led them to neglect information use. However, while 'information use' implies an interaction between two discrete entities (person and information), 'embodiment', provides a richer understanding of the process by which new sense is incorporated into the participants' practices. It is a concept that might greatly enrich our understanding of the information practices of a wide range of groups, from athletes to architects, surgeons to sculptors.

Furthermore, this study opens the possibility of looking at both affect and embodiment through a different theoretical lens: to see them not as the idiosyncratic, acultural behaviours of individuals but as socially constructed, grounded in accepted social norms. If discourse analysis has in recent times given information researchers the theoretical tools to understand language as a social construct - the object and generator of knowledge/power/relations - perhaps it is now time for information researchers to develop theoretical and methodological tools for interrogating the nonlinguistic aspects of information practices.

But that's all one, our play is done, And we'll strive to please you every day.

(Twelfth Night)

\section{References}


Atkins, P. (2001). Information Literacy and the Arts. College and Research Libraries News, 62(11), 1086-8.

Barthes, R. (1988). A Barthes reader. New York, Noonday Press.

Bates, M. (2002). Toward an integrated model of information seeking and searching. The New Review of Information Behaviour Research, 3, 1-15.

Belkin, N. (1990). The cognitive viewpoint in information science. Journal of Information Science. 16, $11-15$

Clark, K. and Archer D. (1999) Bibliography of journal articles indexed in the Institute of Scientific Information databases as citing Brenda Dervin [On-line manuscript]. Previously available at: http://communication.sbs.ohio-state.edu/sense-making/

Cobbledick, S. (1996). The information seeking behaviour of artists: exploratory interviews. Library Quarterly 66(4), 343-72.

Coupland, J. \& Gwyn, R. (2003). Discourse, the body, and identity. Houndmills, Basingstoke, Hampshire; New York : Palgrave Macmillan.

Davies, E. (2007). Epistemic Practices of Theatre Production Professionals: an Activity Theory Approach. Doctoral dissertation: University of Western Ontario .

Davies, E. \& McKenzie, P. J. (2004) 'Preparing for opening night: temporal boundary objects in textually-mediated professional practice' Information Research, 10(1) paper 211. Available at http://informationr.net/ir/10-1/paper211.html

Derrida, J. (1992). Acts of Literature New York: Routledge.

Derrida, J. (1997). Deconstruction in a Nutshell: a Conversation with Jacques Derrida New York Fordham University Press.

Dervin, B. (1999). On studying information seeking and use methodologically: The implications of connecting metatheory to method. Information Processing \& Management, 35, 727-750.

Dervin, B. \& Frenette, M. (2001). Sense-Making Methodology: Communicating communicatively with campaign audiences. In R. E. Rice \& C. K. Atkin (Eds.), Public communication campaigns (3rd ed.). (pp. 69-87). Thousand Oaks, CA: Sage.

Dervin, B. and Nilan, M. (1986). Information needs and uses. Annual Review of Information Science and Technology. 21, 3-33.

Dickens, D.R. \& Fontana, A. (1994). Postmodernism and social inquiry. New York Guilford Press.

Ellis, D. 1993. Modelling the Information-Seeking Patterns of Academic Researchers: a Grounded Theory Approach. Library Quarterly 63 4, 469-486. 
Erdelez, S. (1997). Information encountering: A conceptual framework for accidental information seeking. In P.Vakkari, R. Savolainen \& B. Dervin (Eds) Information Seeking in Context, London: Taylor Graham, 412-421.

Foucault, Michel. (1972). The Archaeology of Knowledge. London Tavistock.

Foucault, Michel. (1977). Discipline and Punish: The Birth of the Prison. London Allen Lane.

Foucault, Michel. (1980). Power/Knowledge: Selected Interviews and Other Writings 1972-1977

London Harvester Press.

Frohmann, B. (1992). The Power of Images: A Discourse Analysis of the Cognitive Viewpoint. Journal of Documentation 48, 365-386.

Glaser, B.G. \& Strauss, A.L. (1967). The discovery of grounded theory: strategies for qualitative research. New York, NY: Aldine Publishing Corporation.

Goffman, E. (1959). The Presentation of Self in Everyday Life University of Edinburgh Social Sciences Research Centre.

Goffman, E. (1983). The Interaction Order. American Sociological Review 48 (1), 1-17.

Golder, J. \& Madelaine, R. (2001) 'To dote on such luggage': Appropriating Shakespeare in Australia. In Golder, John and Madeaine, Richard (eds) O Brave New World: Two Centuries of Shakespeare on the Australian Stage (pp. 1-16). Sydney, Currency Press.

Julien H. (1999). Constructing 'users' in library and information science. Aslib Proceedings 51(6), 206209.

Krikelas, J. (1983). Information-seeking behavior: patterns and concepts. Drexel Library Quarterly 19, 5-20.

Lloyd, A. (2006). Information literacy landscapes: An emerging picture. Journal of Documentation 65, 570-583.

Lloyd, A. (2007). Learning to Put Out the Red Stuff: Becoming Information Literate through Discursive Practice. Library Quarterly. 77 (2), 181-198.

McCrum, R. (1986). The Story of English. London, BBC.

Miles, M. B. and Huberman, A. M.(1994). Qualitative Data Analysis. California: Sage.

Nahl, D. \& Bilal, D. (eds) 2007. Information and Emotion: The Emergent Affective Paradigm in Information Behavior Research and Theory. Medford, NJ: Information Today.

Olsson, M. (1999) 'Discourse: A New Theoretical Framework for Examining Information Behaviour in its Social Context' in Wilson, T.D. and Allen, D.K., eds, (1999) Exploring the Contexts of Information Behaviour - Proceedings of the 2nd Information Seeking in Context Conference Taylor Graham, London. 
Olsson, M. (2005). Meaning and Authority: the Social Construction of an 'author' among Information Behaviour Researchers. Information Research, 10(2) paper 219 available at http://InformationR.net/ir/10-2/paper219.html

Olsson, M. (2007) Power/Knowledge: the Discursive construction of an Author. Library Quarterly. 77 (2), 219-240.

Olsson, M. (2009) Re-Thinking our Concept of Users. Australian Academic \& Research Libraries 40 (1), 22-35.

Patton, M. Q. (2002). Qualitative research \& evaluation methods ( $3 r d$ ed.). Thousand Oaks, CA: Sage Publications.

Pilch, M. (1987) 'Libraries and the amateur theatre' Information and Library Manager; 7(3), 56-58.

Phillips, N. and Hardy, C. (2002). Discourse Analysis. Investigating Processes of Social Construction. Thousand Oaks: Sage.

Rabinow, P. (1984). The Foucault Reader. Harmondsworth, Middlesex, Peregrine Books.

Savolainen, R. (2007) Information Behaviour and Information Practice: Reviewing the 'Umbrella Concepts' of Information-Seeking Studies. Library Quarterly. 77 (2), 109-132.

Seidman, I. E. (1991). Interviewing as qualitative research: a guide for researchers in education and the social sciences. New York, Teachers College Press.

Shakespeare, W. (1623) Mr. William Shakespeares Comedies, Histories. \& Tragedies(First Folio). The Internet Shakespeare Editions

http://internetshakespeare.uvic.ca/Library/facsimile/book/SLNSW F1/3/

Talja, S. (1997). Constituting "information" and "user" as research objects: a theory of knowledge formations as an alternative to the information-man theory'. In Vakkari, P., Savolainen, R. \& Dervin, B. (eds) Information seeking in context : proceedings of an International Conference on Research in Information Needs, Seeking and Use in Different Contexts, 14-16 August, 1996, Tampere, Finland (pp. 67-80) London Taylor Graham.

Williamson, K. (1998). Discovered by chance: the role of incidental information acquisition in an ecological model of information use. Library and Information Science Research, 20 (1), 23-40.

Wilson, P. (1977). Public Knowledge, Private Ignorance: Toward a Library and Information Policy. Greenwood Publishing Group.

Wilson, T.D. (1997). 'Information Behaviour: an Interdisciplinary Perspective' In Vakkari, P., Savolainen, R. \& Dervin, B. (eds) Information seeking in context : proceedings of an International Conference on Research in Information Needs, Seeking and Use in Different Contexts, 14-16 August, 1996, Tampere, Finland (pp. 39-53) London Taylor Graham.

Wilson, T.D. (2000). Human Information Behaviour. Informing Science 3 (1), 49-55. 


\section{Appendix I - Interview Guide}

Thank you for agreeing to take part in my research.

This study seeks to examine the question of how theatre professionals (actors, directors and others) make sense of the works of a culturally iconic author (William Shakespeare). I want to gain an understanding of how your unique experience and expertise has shaped your understanding.

I'd also like to learn more about the ways in which they bring their different views and expertises together to transform words on a page into a living production. I'm interested in the interactions, social practices and relationships by which members of a company may come to a shared understanding of the meaning/s and significance/s of an author's work. Essentially, I am seeking to understand the 'collective sense-making' of theatre professionals - to explore how they answer the question "What does Shakespeare and his work mean in the context of this company/production at this point in space \& time?"

And from this, I'm interested in how your understanding develops and is changed by these experiences - how what you have learned shapes how you think about Shakespeare today and how this shapes your professional life.

In order to understand these processes, however, I need to do so in the context of the experience the 'life-world' - of theatre professionals such as you. I would therefore like you to tell me the 'story' of your relationship with Shakespeare and his work - the events, people and processes that have shaped your sense of the meaning/s \& significance/s of his work - his 'place' \& importance for you as a theatre professional. I would like to hear about events like: events relating to productions you have been part of - read throughs, rehearsals, informal discussions with colleagues; educational experiences - whether at drama school or elsewhere; reading a work by Shakespeare or another author that affected your view of his work; and your use and interpretation of Shakespeare in the course of your own professional life.

Do you have any questions before we begin?

I would like to start by building up a 'timeline' of the important events in your experience of Shakespeare and his work. Could I begin by asking you then to tell me about your first contact with Shakespeare's work...?

\section{Life Line}

WHAT led to/caused EVENT?

- Who initiated?

- Context? [personal., institution, discipline]

WHO/WHAT was involved? 
- Relationship/significance for participant?

- How did their view differ from participant's

- Dynamics of interaction/relationship? Why was their opinion important?

\section{COMPANY/PRODUCTION}

- Part.'s role?

- Key players? (Director, leading cast etc)

- Dynamics of interaction/relationship?

- Agreements/disagreements?

INSTITUTION - TEXT (journal, university, drama school etc)

- Significance for participant? [Reputation etc]

\section{OTHER?}

WHY was EVENT significant?

- How did view/opinion of S CHANGE? Why? [Meaning Construction]

- Relationships/connections made? [e.g. authors, theory]

- How did this relate to participant's life/work as researcher?

WHAT happened next?

- Follow up actions?

- Modifications of behaviour?

\section{General discussion \& summation - Shakespeare \& the Field}

Thank you for sharing those experiences and insights with me. I would now like to ask you some more general questions about Shakespeare's 'place' - in your own work, in the the theatre world, in the academy, and in contemporary society - where you think he and his work 'fits in'.

Why, after 400 years, is Shakespeare and his work still important?

$$
\begin{array}{ll}
\text { - Theatre? } \\
\text { - Society? }
\end{array}
$$

Why is Shakespeare important for you?

What role does Shakespeare play in your own work?

'Field's view' of Shakespeare? 
- How strong?

- How universal?

- Do you agree with it?

- Effect on your behaviour?

How are views of Shakespeare in your country like or unlike views in other parts of the world?

- Similarities/differences

- Significance?

Who views Shakespeare in similar ways to yourself?

- How is it similar?

- Why is this important to you?

- Contact/relationship?

- Kinship/group identification?

Who views Shakespeare in different ways to yourself?

- How is it different?

- Why is this important to you?

Who else do you think I should talk to? Why?

Further points/comments.

Thank you very much for taking part in my research and sharing your insights with me. If, in going over the interview material, I realise there is something I should have talked with you about or an issue comes up in a later interview that I would like you opinion of, is it alright if I contact you again? 